\title{
Hydrodynamic Cavitation - A Promising Technology for Biomass Pretreatment
}

\author{
Ramesh Desikan ${ }^{1 *}$, Kiruthika Thangavelu² and Sivakumar Uthandi ${ }^{3}$ \\ ${ }^{1}$ Department of Vegetable Science, Horticultural College and Research Institute for Women, Tamil Nadu Agricultural University, India \\ ${ }^{2}$ Department of Bioenergy, Agricultural Engineering College and Research Institute, Tamil Nadu Agricultural University, India \\ ${ }^{3}$ Department of Agricultural Microbiology, Tamil Nadu Agricultural University, India
}

Submission: April 26, 2019; Published: May 23, 2019

*Corresponding author: Ramesh Desikan, Department of Vegetable Science, Horticultural College and Research Institute for Women, Tiruchirappalli, Tamil Nadu, 620 027, India

Abstract

Biomass pretreatment is a highly expensive process used in bioethanol production from lignocellulosic feedstocks. The existing pretreatment methods are not commercialized due to two significant bottlenecks faced by the bioethanol industry such as higher operating cost and capital investment. Hydrodynamic cavitation technology is successfully demonstrated in the diversified fields. Hydrodynamic cavitation or its combinations is a viable technology for biomass pretreatment. This technology requires lesser energy inputs in terms of thermal or electrical energy as compared with other energy-intensive pretreatment methods. Other advantages of this technology are simple in reactor construction and easy to upscale. The combined hydrodynamic cavitation with alkali or biocatalyst showed positive results for different lignocellulosic biomass feedstocks. There is more scope for this technology to adopt in commercialization scale in both bioethanol and biorefinery industries.

Keywords: lignocellulsic biomass; Biomass pretreatment; Hydrodynamic cavitation

\section{Introduction}

The cavitation means the phenomena of millions of cavities generated and collapsed in milliseconds and thus dissipating huge magnitudes of energy. Hydrodynamic cavitation, acoustic cavitation, Optic cavitation, and particle cavitation are the four methods classified based on cavitation production mode. Among them, the the first two methods, hydrodynamic cavitation and acoustic cavitation were tried for biomass pretreatment studies due to its simple operation. The hydrodynamic cavitation (HC) is more energy efficient than acoustic cavitation [1,2]. HC can be produced by supplying the liquid at a constant pressure via a constriction arrangement (orifice plate or venturi tube) and energy lost due to a pressure drop at the constriction. This can indirectly help in increasing the liquid velocity, thus helps in collapsing of bubbles in the liquid. In order to generate the cavities, the liquid pressure should reach below the liquid's vapor pressure. The collapse of cavities takes place immediately after pressure recovered.

Application of hydrodynamic cavitation has been found to be adequate for different applications, i.e. biomedical, wastewater treatment [3-6], water treatment [7], biogas production $[8,9]$, cell disruption [10], reactants mixing in chemical reactors [11], biodiesel production [12-18], volatile compound removal [19], delignification of wheat straw for paper pro duction [20], 2,4-dinitrophenol compound degradation [21], 2,4,6-trichlorophenol degradation [22]. Most of the existing pretreatment methods are not commercialized at large scale due to higher energy inputs and capital investment, safety aspects and difficult to upscale. HC technology can handle the large volume of the chemical reactants. Also, there is more scope for application of HC technology to reduce overall processing cost, which indirectly reduces biofuel price. This paper briefly discusses the recent developments in HC technologies in the biomass pretreatment process.

\section{Biomass Pretreatment}

Biofuels can be produced from biomass feedstocks via thermochemical or biochemical biomass conversion technologies. Among the liquid biofuels, bioethanol is recommended for blending with petrol to run the spark ignition engines. First generation bioethanol production technology is successfully implemented at commercial scale in different countries. Because of simple and efficient technology, the fermentable sugars from sugar/starch crops is quickly recovered and used for bioethanol production via a fermentation process. As compared to these crops, the lignocellulosic biomass (LCB) feedstocks have a complex cell wall structure to protect the fermentable sugars. Generally, the LCB feedstocks comprise $75 \%$ of carbohydrates $(40-50 \%$ of 
cellulose, $25-30 \%$ of hemicellulose) and up to $25 \%$ of lignin. The conversion of cellulose and hemicellulose sugars available in the LCB feedstocks into fermentable sugars is a difficult task due to lignin binding. The LCB feedstocks into bioethanol production via biochemical conversion technologies involve three stages. Firstly, the biomass undergoes the pretreatment to break the lignin barrier. Secondly, the hydrolysis process used for cellulose and hemicellulose sugars to produce fermentable sugars. Lastly, the production of bioethanol from these sugars can be done by the fermentation process. There are no efficient technologies available for pretreating the LCB feedstocks. Biomass pretreatment is an essential process for cellulosic ethanol production. Currently, physical, chemical, biological and combined pretreatments (two or more) are the primary techniques employed. In comparison to individual pretreatment method, combined pretreatments are focused much more attention due to its improved pretreatment performance.

\section{Discussion}

\section{HC technology for biomass pretreatment}

Several researchers have involved in developing an efficient method to pretreat the different LCB feedstocks via physical or chemical or physicochemical or biological or combination of two or more methods. Recent review paper covers various aspects (including merits and demerits) of different biomass pretreatment methods viz.,

a) physical (mechanical extrusion, milling, microwave, ultrasound, pyrolysis and pulse electric field),

b) Chemical (acid, alkali, ozonolysis, organosolv, ionic liquids, and eutectic solvents)

c) physicochemical (steam explosion, liquid hot water, etc.) and

d) biological (fungi, bacterial and archaeal) methods [23].

Based on the conclusion drawn from the literature review, the current biomass pretreatment methods used for LCB feedstocks were the more complicated process, energy intensive and difficult to upscale. The primary reason may be due to the involvement of higher energy inputs (electrical/thermal energies) and processing cost. In order to overcome these issues, HC technology can be combined with other pretreatment methods for the effective pretreatment of LCB feedstocks.

In order to improve pretreatment efficiency, HC can be combined with existing chemical or biological methods. At the time of the cavitation process, dissociation of the water molecule into $\mathrm{OH}-$ and $\mathrm{H}$ - produced at higher pressure and temperature conditions. The $\mathrm{OH}$ - radicals generated in the cavitation process are more reactive, which can play an essential role in oxidization of lignin molecule. Orifice plate and venturi tube are commonly used in the reactor to produce HC. There is no mechanism used for mixing of reactants in the reactor. The radicals formed in the reaction can be used to enhance the pretreatment performance. Depend- ing on the reactor geometry and configuration, the biomass pretreatment in $\mathrm{HC}$ reactor was done in two ways. One method uses biomass kept in HC zone and chemical solution (water + catalyst) as working fluid to pass through biomass (HC zone) for several times using closed loop arrangement. Another method uses biomass slurry as working liquid and sent to HC zone several times through closed loop circulation [24]. The results of a comparative study showed that performance of alkali biomass pretreatment in HC reactor with an orifice plate was better in terms of energy requirement, lignin reduction and bioethanol yield than ultrasound cavitation method [25]. The pretreatment was done by keeping reed biomass in the $\mathrm{HC}$ zone and working fluid is circulated for the reaction period. Higher lignin reduction was achieved as 35$42 \%$ under optimal conditions of $11.8 \%$ biomass loading, $3.0 \%$ $\mathrm{NaOH}$ and reaction $41.1 \mathrm{~min}$ (Table 1). Another study on combined $\mathrm{HC}$ and alkaline pretreatment to pretreat the sugarcane bagasse using $\mathrm{HC}$ reactor with an orifice plate showed maximum lignin removal as $60.4 \%$ in $44.48 \mathrm{~min}$ [26]. Further enzymatic hydrolysis shows that yield from pretreated biomass was higher than raw $(82 \%)$ and alkaline treated biomass (30\%). Another similar study showed maximum lignin was $51.52 \%$ in $30 \mathrm{~min}$ [27]. This might be due to differences in biomass types, reactor geometry configurations, operating and optimal conditions used in the experiments. A combination of alkali and $\mathrm{HC}$ was used to pretreat the sugarcane bagasse feedstock for bioethanol production via simultaneous saccharification and fermentation (SSF) process [28]. Among the different alkaline catalysts used $(\mathrm{NaOH}, \mathrm{KOH}$, $\mathrm{Na}_{2} \mathrm{CO}_{3}, \mathrm{Ca}(\mathrm{OH})_{2}$ ), the combined $\mathrm{NaOH}-\mathrm{HC}$ pretreatment achieved the highest amount of ethanol production (17.26 g.l-1). Results of the combined HC and hydrogen peroxide pretreatment of sugarcane bagasse showed $95.4 \%$ of cellulosic fraction digestibility was reached under optimal conditions $(0.29 \mathrm{M}$ of $\mathrm{NaOH}, 0.78 \%(\mathrm{v} / \mathrm{v})$ of $\mathrm{H}_{2} \mathrm{O}_{2}, 9.95 \mathrm{~min}$.) $[29,30]$. They also reported that bioethanol yield from pretreated biomass by Scheffersomyces stipites NRRL-Y7124 in a bubble column reactor was achieved as 31.50 g.l $\mathrm{l}^{-1}$ Nakashima et al. [31] studied a comparative pretreatment using a reactor with a venturi tube and ultrasonication for combined $\mathrm{HC}$ with catalyst (sodium percarbonate) to pretreat the corn stover biomass. The biomass slurry (water +biomass powder +chemical solution) was used as a working liquid and continuously re-circulated via a venturi tube for the reaction period. They found that the biomass pretreatment efficiency in the HC method was higher than the ultrasonication method. The combined HC and enzymatic (HCE) method were evaluated as corncob pretreatment by using biomass slurry (buffer + biomass powder +enzyme) as working liquid and continuously re-circulated via orifice plate for the reaction period [24]. They found the highest lignin reduction (47.4\%) under the optimal conditions (biomass loading: 5\%, enzyme loading: $6.5 \mathrm{U}$ $\mathrm{g}^{-1}$ of biomass and reaction time: $60 \mathrm{~min}$.). Hence, application of HC in biomass pretreatment has gained interest when compared to conventional methods of pretreatment viz., higher removal of lignin, easy accessibility of cellulose for saccharification, less energy consumption, simple geometric configuration, construction and easy to scale up. 
Table 1: Comparison of combined HC with different catalysts to pretreat the various lignocellulosic biomass feedstocks.

\begin{tabular}{|c|c|c|c|c|c|c|c|}
\hline $\begin{array}{l}\text { S. } \\
\text { No. }\end{array}$ & Parameters & $\begin{array}{c}\text { Kim et al. } \\
\text { [25] }\end{array}$ & $\begin{array}{c}\text { Hilares et al. } \\
\text { [26] }\end{array}$ & $\begin{array}{c}\text { Nakashima et al. } \\
\text { [31] }\end{array}$ & $\begin{array}{c}\text { Madison et al. } \\
{[30]}\end{array}$ & $\begin{array}{c}\text { Hilares et al. } \\
\text { [28] }\end{array}$ & $\begin{array}{c}\text { Kiruthika et al. } \\
\text { [24] }\end{array}$ \\
\hline 1 & $\begin{array}{c}\text { Cavitational device } \\
\text { used }\end{array}$ & Orifice & Orifice & Venturi & Venturi & Orifice & Orifice \\
\hline 2 & $\begin{array}{l}\text { Orifice hole dia (nos) } \\
\text { / throat dia }\end{array}$ & $\emptyset=1 \mathrm{~mm},(27)$ & $\emptyset=1 \mathrm{~mm},(27)$ & throat $\emptyset=3.6 \mathrm{~mm}$ & $\begin{array}{c}\text { throat } \emptyset=5.72 \\
\mathrm{~mm}\end{array}$ & $\emptyset=1 \mathrm{~mm},(16)$ & $\emptyset=2 \mathrm{~mm},(27)$ \\
\hline 3 & $\begin{array}{l}\text { Operating tempera- } \\
\text { ture, }{ }^{\circ} \mathrm{C}\end{array}$ & 77 & 64 & 30 & 22 & 70 & 30 \\
\hline 4 & Inlet pressure, $\mathrm{kPa}$ & 500 & 300 & - & 370 & 300 & 50 \\
\hline 5 & Feedstock used & Reed & $\begin{array}{l}\text { Sugarcane } \\
\text { bagasse }\end{array}$ & Corn stover & Sugarcane bagasse & $\begin{array}{l}\text { Sugarcane } \\
\text { bagasse }\end{array}$ & Corncob \\
\hline 6 & Feedstock size & $10 \mathrm{~mm}$ & $4.7 \mathrm{~mm}$ & $0.25 \mathrm{~mm}$ & 10 mesh size & $4.7 \mathrm{~mm}$ & $\leq 212 \mu \mathrm{m}$ \\
\hline 7 & Biomass loading, \% & 11.8 & 4.24 & 4 & 1 & -- & 5 \\
\hline 8 & Catalyst & $3.0 \% \mathrm{NaOH}$ & $0.48 \mathrm{M} \mathrm{NaOH}$ & $\begin{array}{c}0.4 \mathrm{~mol} / \mathrm{L} \text { of } \\
\mathrm{Na}_{2} \mathrm{CO}_{3}, 0.6 \mathrm{~mol} / \mathrm{L} \\
\text { of } \mathrm{H}_{2} \mathrm{O}_{2}\end{array}$ & $\begin{array}{c}\mathrm{Ca}(\mathrm{OH})_{2}-0.1 \mathrm{~g} / \mathrm{g} \text { of } \\
\text { dry biomass }\end{array}$ & $0.3 \mathrm{M} \mathrm{NaOH}$ & $\begin{array}{l}\text { Laccase Enzyme: } \\
6.5 \mathrm{U} \mathrm{g}^{-1} \text { of biomass }\end{array}$ \\
\hline 9 & Working fluid & $\begin{array}{l}\text { Water + cata- } \\
\text { lyst solution }\end{array}$ & $\begin{array}{l}\text { Water + cata- } \\
\text { lyst solution }\end{array}$ & $\begin{array}{c}\text { Biomass slurry } \\
\text { (water + catalyst } \\
\text { +biomass powder) }\end{array}$ & $\begin{array}{c}\text { Biomass slurry } \\
\text { (water + catalyst } \\
\text { +biomass powder) }\end{array}$ & $\begin{array}{l}\text { Water + catalyst } \\
\text { solution }\end{array}$ & $\begin{array}{c}\text { Biomass slurry } \\
\text { (water + catalyst } \\
+ \text { biomass powder) } \\
\end{array}$ \\
\hline 11 & Duration, min. & 41.1 & 44.48 & 60 & 120 & 30 & 60 \\
\hline 12 & Lignin removal, \% & $35-42$ & 60.4 & - & 36 & 51.52 & 47.44 \\
\hline 13 & Energy consumption, & $\begin{array}{c}3.65 \mathrm{MJ} \mathrm{kg}{ }^{-1} \text { of } \\
\text { biomass }\end{array}$ & -- & $9.4 \mathrm{~kJ} / \mathrm{g}$ sugar & $752 \mathrm{~kJ} / \mathrm{g}$ sugar & -- & $\begin{array}{c}1.35 \mathrm{MJ} \mathrm{kg}^{-1} \text { of } \\
\text { biomass }\end{array}$ \\
\hline
\end{tabular}

\section{Factors affecting the HC pretreatment}

The bubble size describes the intensity of cavitation and grows at low pressure or high temperature [32]. As compared to smaller bubbles, larger bubbles collapsing with a higher intensity would have significant effects on reactants used in the chemical process. For instance, collapsing of vast numbers of bubbles using the process can deconstruct the biomass structure. In the case of working fluid with highly viscous nature and low vapor pressure, more energy is required to produce cavitation. Furthermore, the size and reactor geometry can also affect the pretreatment efficiency [33]. The cavitation number $\mathrm{Cv}$ is a measure of resistance to cavitation. A higher value of $\mathrm{Cv}$ indicates cavitation will not take place and vice versa. Low cavitation number can increase the cavitation intensity, which can be achieved by reduce the pressure or increase the flow rate of the working fluid [33]. Sometimes the bubbles may combine to form a larger bubble at low cavitation numbers, and they may be carried away with the liquid. This would lower the effectiveness of the cavitation process [34]. The significant parameters affect the intensity of cavitation during the biomass pretreatment are particle size, catalyst activity, inlet pressure, temperature and diameter of the orifice plate.

\section{Conclusion}

Recently, HC technology is a good candidate among the other pretreatment methods for pretreating the LCB feedstocks. The large-scale application of this technology has potential to reduce pretreatment process cost. In comparison with the HC process, the combined (HC and other pretreatment methods) biomass pretreatment can increase the overall performance of the pretreatment process. HC technology can also offer a possibility for continuous biomass pretreatment process. The viability of technology can be judged based on their technical, economical and life cycle assessment aspects. Application of HC process on the deconstruction of biomass should be validated in both batch and continuous mode of operations. For above-said reasons, optimization of process parameters and their interactions on overall pretreatment efficiency must be studied in detail for different LCB feedstocks.

\section{References}

1. Gore MM, Saharan VK, Pinjari DV, Chavan PV, Pandit AB (2014) Degradation of reactive orange 4 dye using hydrodynamic cavitation based hybrid techniques. Ultrason Sonochem 21(3):1075-1082.

2. Ji J, Wang J, Li Y, Yu Y, Xu Z (2006) Preparation of biodiesel with the help of ultrasonic and hydrodynamic cavitation. Ultrasonics 44 Suppl 1: e411-e414.

3. Wu ZL, Ondruschka B, Bräutigam P (2007) Degradation of chlorocarbons driven by hydrodynamic cavitation. Chem Eng Technol 30(5): 642-648.

4. Joshi RK, Gogate PR (2012) Degradation of dichlorvos using hydrodynamic cavitation based treatment strategies. Ultrason Sonochem 19(3): 532-539.

5. Patil PN, Gogate PR (2012) Degradation of methyl parathion using hydrodynamic cavitation: Effect of operating parameters and intensification using additives. Sep Purif Technol 95: 172-179.

6. Dular M, Griessler-Bulc T, Gutierrez-Aguirre I, Heath E, Kosjek T, et al. (2016) Use of hydrodynamic cavitation in (waste) water treatment. Ultrason Sonochem 29: 577-588. 
7. Tao Y, Cai J, Huai X, Liu B, Guo Z, (2016) Application of hydrodynamic cavitation into wastewater treatment: a review. Chem Eng Technol 39(8): 1363-1376.

8. Patil PN, Gogate PR, Csoka L, Dregelyi-Kiss A, Horvath M (2016) Intensification of biogas production using pretreatment based on hydrodynamic cavitation. Ultrason Sonochem 30: 79-86.

9. Garuti M, Langone M, Fabbri C, Piccinini S (2018) Monitoring of fullscale hydrodynamic cavitation pretreatment in agricultural biogas plant. Biores Tech 247: 599-609.

10. Lee AK, Lewis DM, Ashman PJ (2015) Microalgal cell disruption by hydrodynamic cavitation for the production of biofuels. J Appl Phycol 27(5): 1881-1889.

11. Pandit AB, Kumar PS, Kumar MS (1999) Improve reactions with hydrodynamic cavitation. Chem Eng Prog 95(5): 43-50.

12. Gogate PR (2008) Cavitational reactors for process intensification of chemical processing applications: a critical review. Chem Eng Process 47(4): 515-527

13. Kelkar MA, Gogate PR, Pandit AB (2008) Intensification of esterification of acids for synthesis of biodiesel using acoustic and hydrodynamic cavitation. Ultrason Sonochem 15(3): 188-194.

14. Pal A, Verma A, Kachhwaha SS, Maji S (2010) Biodiesel production through hydrodynamic cavitation and performance testing Renew Energy 35(3): 619-624.

15. Ghayal D, Pandit AB, Rathod VK (2013) Optimization of biodiesel production in a hydrodynamic cavitation reactor using used frying oil. Ultrason Sonochem 20(1): 322-328.

16. Gole VL, Naveen KR, Gogate PR (2013) Hydrodynamic cavitation as an efficient approach for intensification of synthesis of methyl esters from sustainable feedstock. Chem Eng Process 71: 70-76.

17. Chuah LF, Yusup S, Aziz ARA, Bokhari A, Abdullah MZ (2016) Cleaner production of methyl ester using waste cooking oil derived from palm olein using a hydrodynamic cavitation reactor. J Clean Prod 112: 4505 4514 .

18. Chitsaz H, Omidkhah M, Ghobadian B, Ardjmand M (2018) Optimization of hydrodynamic cavitation process of biodiesel production by response surface methodology. J Environ Chem Eng 6(2): 2262-2268.

19. Arias FJ, De las Heras S (2017) Use of hydrodynamic cavitation for volatile removal compound. International Journal of Heat and Fluid Flow 66: 1-7.

20. Badve MP, Gogate PR, Pandit AB, Csoka L (2014) Hydrodynamic cavitation as a novel approach for delignification of wheat straw for paper manufacturing. Ultrason Sonochem 21(1): 162-168.

21. Bagal MV, Gogate PR (2013) Degradation of 2, 4-dinitrophenol using a combination of hydrodynamic cavitation, chemical, and advanced oxidation processes. Ultrason Sonochem 20(5): 1226-1235.
22. Barik AJ, Gogate PR (2018) Hybrid treatment strategies for 2, 4, 6-trichlorophenol degradation based on combination of hydrodynamic cavitation and AOPs. Ultrason Sonochem 40(Pt A): 383-394.

23. Kumar AK, Sharma S (2017) Recent updates on different methods of pretreatment of lignocellulosic feedstocks: a review. Bioresour Bioprocess 4(1): 7 .

24. Kiruthika T, Ramesh D, Taran OP, Sivakumar U (2018) Delignification of corncob via combined hydrodynamic cavitation and enzymatic pretreatment: process optimization by response surface methodology. Biotechnol Biofuels 11(1): 203.

25. Kim I, Lee I, Jeon SH, Hwang T, Han JI (2015) Hydrodynamic cavitation as a novel pretreatment approach for bioethanol production from reed. Biores Tech 192: 335-339.

26. Hilares RT, dos Santos JC, Ahmed MA, Jeon SH, da Silva SS, et al. (2016) Hydrodynamic cavitation-assisted alkaline pretreatment as a new approach for sugarcane bagasse biorefineries. Biores Tech 214: 609614.

27. Hilares RT, de Almeida GF, Ahmed MA, Antunes FAF, da Silva SS, et al. (2017a) Hydrodynamic cavitation as an efficient pretreatment method for lignocellulosic biomass: A parametric study. Biores Tech 235: 301308.

28. Hilares RT, Ienny JV, Marcelino PF, Ahmed MA, Antunes FA, et al. (2017b) Ethanol production in a simultaneous saccharification and fermentation process with interconnected reactors employing hydrodynamic cavitation-pretreated sugarcane bagasse as raw material. Biores Tech 243: 652-659.

29. Hilares RT, Kamoei DV, Ahmed MA, da Silva SS, Han JI, et al. (2018) A new approach for bioethanol production from sugarcane bagasse using hydrodynamic cavitation assisted-pretreatment and column reactors. Ultrason Sonochem 43: 219-226.

30. Madison MJ, Coward-Kelly G, Liang C, Karim MN, Falls M, et al. (2017) Mechanical pretreatment of biomass-Part I: Acoustic and hydrodynamic cavitation. Biomass Bioenergy 98: 135-141.

31. Nakashima K, Ebi Y, Shibasaki-Kitakawa N, Soyama H, Yonemoto T (2016) Hydrodynamic cavitation reactor for efficient pretreatment of lignocellulosic biomass. Ind Eng Chem Res 55(7): 1866-1871.

32. Segal L, Creely JJ, Martin AE, Conrad CM (1959) An empirical method for estimating the degree of crystallinity of native cellulose using the X-ray diffractometer. Text Res J 29(10): 786-794.

33. Shah YT, Pandit AB, Moholkar VS (1999) Cavitation Reaction Engineering, Springer Science and Business Media, New York.

34. Kumar PS, Kumar MS, Pandit AB (2000) Experimental quantification of chemical effects of hydrodynamic cavitation. Chem Eng Sci 55(9): 1633-1639. 
Your next submission with Juniper Publishers will reach you the below assets

- Quality Editorial service

- Swift Peer Review

- Reprints availability

- E-prints Service

- Manuscript Podcast for convenient understanding

- Global attainment for your research

- Manuscript accessibility in different formats ( Pdf, E-pub, Full Text, Audio)

- Unceasing customer service

Track the below URL for one-step submission https://juniperpublishers.com/online-submission.php 